JURNAL PENGELOLAAN LABORATORIUM SAINS DAN TEKNOLOGI

ISSN (Online):

Available Online at https://ejournal.unib.ac.id/index.php/labsaintek/index

DOI: https://doi.org/10.33369/labsaintek.v1i1.15457

\title{
EVALUASI PEMANFAATAN GOOGLE FORM SEBAGAI ALAT PEMINJAMAN DAN PENGEMBALIAN DALAM PENGELOLAAN LABORATORIUM KEPERAWATAN PADA MASA PANDEMI COVID 19
}

\author{
${ }^{1}$ Santi Zulmedia \\ ${ }^{1}$ Universitas Bengkulu \\ Korespondensi: santizulmedia@unib.ac.id
}

\begin{abstract}
Abstrak
Tujuan penelitian adalah menganalisis dan mendeskripsikan pemanfaatan teknologi informasi komputer (TIK) oleh Pranata Laboratorium Pendidikan (PLP) dalam pengelolaan laboratorium khusus administrasi peminjaman dan pengembalian alat praktikum . Penelitian menggunakan metode kuantitatif deskriptif persentase. Sampel penelitian adalah mahasiswa prodi D3 keperawatan FMIPA UNIB yang sudah pernah melakukan peminjaman alat, dengan teknik pengambilan sample secara cluster sampling. Teknik pengumpulan data dilakukan melalui kuisionare. Hasil penelitian menunjukkan (1) Menggunakan Google Form mudah di akses memperoleh hasil $81 \%$, (2) Menggunakan Google Form mudah di akses memperoleh hasil $70 \%$ (3) Menggunakan google Form dapat menghemat kertas memperoleh hasil $66 \%$ (4) Menggunakan Google Form mudah di pahami memperoleh hasil $88 \%$, (5) Menggunakan Google Form menarik dan mudah di mengerti Memperoleh hasil $90 \%$, (6) Bahasa yang digunakan dalam Google Form sudah sesuai memperoleh hasil $73 \%$.
\end{abstract}

Kata kunci: manajemen, sampah medis

\begin{abstract}
The purpose of the study was to analyze and describe the use of ICT by the Education Laboratory Institution (PLP) in the management of a special laboratory for the administration of borrowing and returning equipment. This research uses descriptive quantitative method of percentage. The research sample was a student of the $\mathrm{d} 3$ nursing study program, FMIPA UNIB, who had already borrowed equipment, using cluster sampling technique. The collection technique is done through a questionnaire. The results showed (1) Using the Google Form was easy to access, getting $81 \%$ results, (2) Using the Google Form was easy to access and getting 70\% results (3) Using the Google Form could save paper and getting 66\% results (4) Using the Goegle Form was easy understood to get 88\% results, (5) Using the Google Form is interesting and easy to understand Gets $90 \%$ results, (6) The language used in the Google Form is appropriate to get $73 \%$ results.
\end{abstract}

Keywords: management, medical waste

\section{PENDAHULUAN}

Salah satu aplikasi di internet yang dapat digunakan dalam mendukung kegiatan di pendidikan pengelolaan adalah aplikasi Google Form. Aplikasi ini merupakan inovasi dari Google Docs yang dapat digunakan untuk membuat pertanyaan berupa kuisioner atau formulir pendaftaran sebuah acara secara online, mengelola pendaftaran acara, membuat polling quick count pendapat dengan cepat melalui Google, dan sebagainya. Platform Google doc ini tidak dipungut biaya sepeserpun. Google Form atau yang disebut google formulir adalah alat yang 
berguna untuk membantu anda merencanakan kegiatan, mengirim survei, memberikan siswa atau orang lain kuis, atau mengumpulkan informasi yang mudah dengan cara yang efisien. Form juga dapat dihubungkan ke spreadsheet. Jika spreadsheet terkait dengan bentuk, tanggapan otomatis akan dikirimkan ke spreadsheet. Jika tidak, pengguna dapat melihat mereka di "Ringkasan Tanggapan" halaman dapat diakses dari menu Tanggapan (Hamdan Husein Batubara, 2016). Salah satu alasan dari banyak pengguna yang mungkin tidak menyadari Google Form adalah bahwa mereka ditemukan bukan sebagai aplikasi terpisah, melainkan sebagai bagian dari Google Drive. Dengan demikian, untuk membuat formulir baru, anda harus terlebih dahulu login ke gmail atau Google Apps. Dengan Spreadsheets memungkinkan untuk menunjukan bagaimana anda dapat menggunakan software ini untuk mengajukan berbagai pertanyaan, termasuk dimana pengguna anda merespon dengan jawaban teks sederhana atau respon teks lebih lanjut. Anda dapat meminta pertanyaan pilihan ganda, daftar pertanyaan, pertanyaan skala, dan masih banyak lagi. Ketika berbagi formulir anda dengan orang lain, anda dapat mengatur mereka untuk tampil dengan tema yang mengesankan dengan akses yang mudah.

Adapun beberapa keunggulan pembuatan penilaian kinerja petugas laboratorium pada proses pembelajaran menggunakan Google Form adalah: 1) Tampilan Form yang menarik. Aplikasi ini menyediakan fasilitas kepada penggunanya untuk memasukkan dan menggunakan foto atau logonya sendiri di dalam survey tersebut. Aplikasi ini juga memiliki banyak template yang membuat kuis dan kuesioner online tersebut semakin menarik dan berwarna. 2) Memiliki berbagai jenis tes yang bebas dipilih. Aplikasi ini menyediakan fasilitas pilihan tes yang bebas digunakan sesuai dengan keperluan pengguna. Misalnya pilihan jawaban pilihan ganda, ceklis, tarikturun, skala linier, dan lain sebagainya. Anda juga dapat menambahkan gambar dan video YouTube ke dalam kuis anda. 3) Responden dapat memberikan tanggapan dengan segera di mana pun. Aplikasi ini dapat digunakan setiap orang secara gratis untuk membuat kuisioner online dan kuis online menggunakan laptop atau handphone yang terhubung dengan internet lalu membagikan alamat link formnya kepada para responden sasaran atau menempelkannya di sebuah halaman website. Para respondennya dapat memberikan tanggapannya dimanapun dan kapanpun dengan mengklik alamat web atau link yang dibagikan pembuat kuisioner tersebut menggunakan komputer atau handphone yang terhubung ke internet. Semua tanggapan dan jawaban orang lain akan secara otomatis ditampung, disusun, dianalisa dan disimpan oleh aplikasi Google Form dengan cepat dan aman. 4) Formulirnya responsive. Berbagai jenis kuis dan kuesioner dapat dibuat dengan mudah, lancar dan hasilnya tampak profesional dan indah. 5) Hasilnya langsung tersusun dianalisis secara otomatis. Tanggapan survei anda dikumpulkan dalam formulir dengan rapi dan secara otomatis, disertai info tanggapan waktu nyata dan grafik hasil tanggapan. Pengguna juga dapat melangkah lebih jauh bersama hasil data dengan melihat semuanya di Spreadsheet, yakni aplikasi semacam Ms. Office Excel. 6) Dapat dikerjakan bersama orang lain. Kuisioner dan Quiz menggunakan aplikasi ini dapat dikerjakan bersama orang lain atau siapa saja yang diinginkan oleh pengguna. Berdasarkan uraian di atas, dapat dikatakan bahwa supervisi pengelolaan yang dilakukan dengan menggunakan Google Form sebagai media atau alat bantu, maka pelaksanaan supervisi tersebut bisa lebih efektif dan eifisien karena: (1) Menggunakan google Form mudah di akses, (2) dapat menghemat kertas, (3) mudah di pahami, (4) menarik dan mudah di mengerti, (5) google Form sudah sesuai digunakan pada masa pandemi.

Oleh karena itu, di zaman sekang ini yang serba internet, maka sangat disayangkan jika para pangawas tidak memanfaatkan keunggulan yang dimiliki oleh Google Form sebagai alat bantu dalam melakukan supervisi akademik. Google Form merupakan salah satu komponen layanan Google Docs. Aplikasi ini sangat cocok untuk mahasiswa, guru, dosen, pegawai kantor dan professional yang senang membuat quiz, form dan survey online. Fitur, dari Google Form dapat di bagi ke orang-orang secara terbuka atau khusus kepada pemilik akun Google dengan 
pilihan aksesibilitas, seperti: read only (hanya dapat membaca) atau editable (dapat mengedit dokumen). Selain itu, Google docs juga dapat menjadi alternatif bagi orang-orang yang tidak memiliki dana untuk membeli aplikasi berbayar untuk menggunakan program gratisan dibandingkan membajak program berbayar seperti Microsoft Office, karena kita tahu bahwa membajak program itu adalah tidak baik. Adapun beberapa fungsi Google Form untuk dunia pendidikaan adalah sebagai berikut: 1) Memberikan tugas latihan/ ulangan online melalui laman website, 2) Mengumpulkan pendapat orang lain melalui laman website, 3) Mengumpulkan berbagai data mahasiswa/dosen melalui halaman website, 4) Membuat formulir pendaftaran online untuk sekolah, 5) Membagikan kuesioner kepada orang-orang secara online.

Aplikasi ini berbasis web maka setiap orang dapat memberikan tanggapan atau jawaban terhadap kuis ataupun kuisioner secara cepat dimanapun ia berada dengan menggunakan aplikasi internet komputer/ laptop ataupun Handphone. Karena itu, dengan menggunakan aplikasi ini maka seorang PLP atau pegawai tidak memerlukan kertas lagi untuk mencetak kuis atau kuisionernya. Waktu yang diperlukannya juga akan semakin hemat dalam membagikan, mengumpulkan kembali dan menganalisis hasil kuis dan angketnya. Dengan demikian, aplikasi ini sangat cocok digunakan untuk mengumpulkan pendapat sekelompok orang yang berjauhan dan sulit dikumpulkan, mengelola pendaftaran acara atau sekolah melalui halaman internet, mengumpulkan data-data, membuat kuis mendadak, dan banyak lagi.

\section{METODE PENELITIAN}

Metode yang digunakan dalam penelitian ini adalah kuantitatif deskriptif persentase. Populasi dalam penelitian ini adalah mahasiswa D3 Keperawatan. Sedangkan sampel dalam penelitian ini adalah mahasiswa yang sudah melakukan peminjaman alat di laboratorium. Pengambilan sampel penelitian menggunakan teknik cluster sampling, yaitu menentukan sampel dari sebagian populasi yang mewakili saja. Alasan pemilihan ini karena mahasiswa yang sudah pernah melakukan pemnijaman alat dianggap telah mengetahui proses dan cara peminjamn alat menggunakan aplikasi google form ini. Metode yang digunakan dalam pengumpulan data berupa kuesioner dalam bentuk check list untuk mengetahui pemanfaatan google form dalam peminjaman dan pengembalian alat laboratorium. Angket tertutup dengan 4 pilihan jawaban yang diberikan kepada siswa sebagai data pendukung penelitian pemanfaatan google form dalam peminjaman dan pengembalian alat laboratorium.

Analisis data hasil penelitian dilakukan dengan menganalisis analisis evaluasi pemanfaatan google form dalam peminjaman dan pengembalian alat laboratorium diperoleh dari hasil kuesioner yang dilakukan oleh mahasiswa. Penilaian terhadap evaluasi pemanfaatan google form dalam peminjaman dan pengembalian alat laboratorium meliputi penilaian kesukaan mahasiswa, pemahaman, kemiudahan dan efisen dan efekstif. Hasil observasi dianalisis menggunakan metode kuantitatif deskriptif persentase untuk menunjukkan tingkat pemanfaatan pemanfaatan google form dalam peminjaman dan pengembalian alat laboratorium oleh mahasiswa dalam kegiatan di laboratorium. Adapun hasil analisis dinyatakan sangat tinggi apabila mencapai rentang persentase 80 hingga 100, tinggi pada rentang 60 hingga 79, sedang pada rentang 40 hingga 59, rendah pada rentang 20 hingga 39, dan sangat rendah di bawah 19.

\section{HASIL DAN PEMBAHASAN}

Penelitian dilakukan selama satu bulan, pengumpulan data diperoleh dengan observasi, dokumentasi dan penyebaran kuesioner dari tanggal 03 Februari 2021 sampai dengan 03 maret 2021. Objek penelitian adalah mahasiswa keperawatan yang telah melakukan peminjaman alat secara online. Pengumpulan data pada penelitian ini diperoleh menggunakan instrumen berupa kuesioner dengan jumlah jumlah pertanyaan 7 soal. Hasil penelitian dan pembahasan ini di 
deskripsikan dari lima pertanyaan hasil survey yang dilakukan terhadap 135 responden. Adapun deskripsi dari masing-masing bagian adalah sebagai berikut.

Deskripsikan hasil penelitian per setiap pertanyaan

1. Deskripsi Respon responden

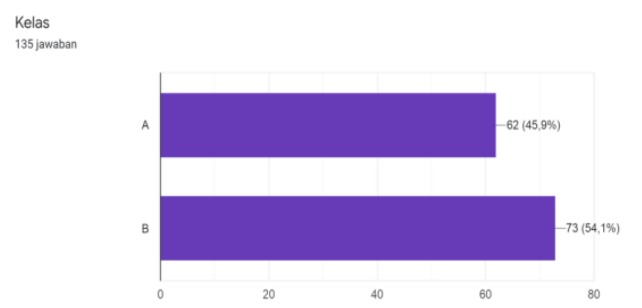

Gambar 1. Deskripsi respon Responden

Berdasarkan data pada gambar 1 diperoleh hasil, respon responden yang memberikan respon terhadap Kuesioner Evaluasi Pemanfaatan Google Form Sebagai Alat Peminjaman Dan Pengembalian Dalam Pengelolan Laboratorium Laboratorium Keperawatan Masa Pandemi Covid 19 adalah kelas A Mencapai 73 orang (54,1\%), Kelas B 62 Orang (45,9\%.)

2. Menyukai pelayanan laboratorium menggunakan Google Form di masa pandemi Covid-19

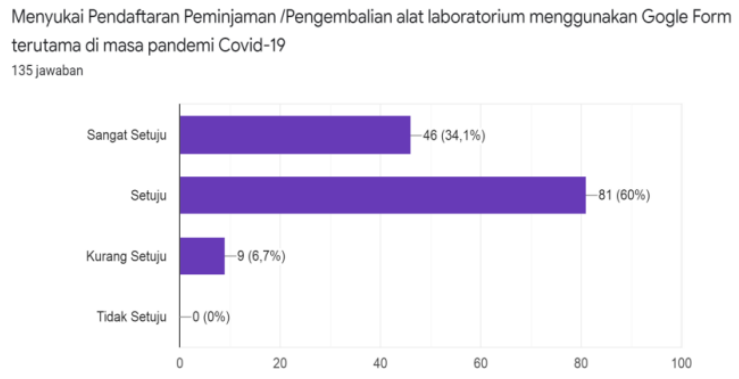

Berdasarkan data pada gambar 2 diperoleh hasil, respon responden yang memberikan respon terhadap Kuesioner Evaluasi Pemanfaatan Google Form Sebagai Alat Peminjaman Dan Pengembalian Dalam Pengelolan Laboratorium Laboratorium Keperawatan Masa Pandemi Covid 19 adalah yang menyatakan sangat setuju $46(34,1)$ setuju berjumlah 81 Orang $(60 \%)$, kurang setuju 9 orang $(6,7 \%)$ dan tidak setuju berjumlah 0 orang $(0 \%)$.

Dari data diatas dapat disimpulkan bahwa rata mahasiswa prodi D3 keprawatan FMIPA menyukai peminjaman alat-alat laboratorium menggunakan aplikasi google form. Dengan peminjaman alat secara online tidak membatasi mahasiswa dalam menyiapkan pembelajaran praktik sekalipun dengan kondisi pandemi yang sampai saat ini masih mewabah.

3. Menggunakan Google Form mudah di akses

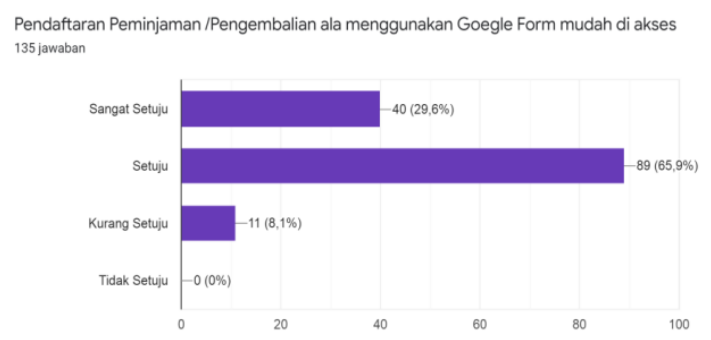

Berdasarkan data pada gambar 2 diperoleh hasil, respon responden yang memberikan respon terhadap Kuesioner evaluasi pemanfaatan google form sebagai alat peminjaman dan 
pengembalian dalam pengelolan Laboratorium Keperawatan Masa Pandemi Covid 19 adalah yang menyatakan sangat setuju $40(29,6)$ setuju berjumlah 89 Orang $(65,9 \%)$, kurang setuju 11 orang $(8,1 \%)$ dan tidak setuju berjumlah 0 orang $(0 \%)$.

Dari data diatas dapat disimpulkan bahwa rata - rata mahasiswa prodi D3 keprawatan FMIPA menyimpulkan peminjaman alat-alat laboratorium menggunakan aplikasi google form. Dengan peminjaman alat secara online mudah di akses namun ada beberapa orang yang beranggapan peminjaman online susah di akses, di karenakan belum memahami dan sinyal atau kuota yang tidak mendukung.

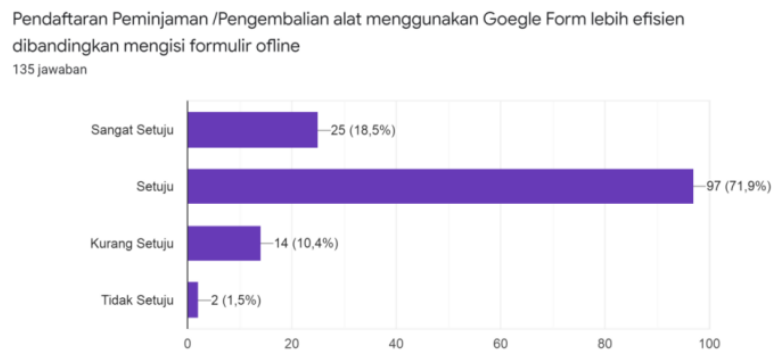

Berdasarkan data pada gambar 2 diperoleh hasil, respon responden yang memberikan respon terhadap Kuesioner evaluasi pemanfaatan google form sebagai alat peminjaman dan pengembalian dalam pengelolan Laboratorium Keperawatan Masa Pandemi Covid 19 adalah yang menyatakan sangat setuju 25 orang (18,5\%) setuju berjumlah 97 Orang (71,9\%), kurang setuju 14 orang $(10,47 \%)$ dan tidak setuju berjumlah 2 orang $(1,5 \%)$.

Dari data diatas dapat disimpulkan bahwa rata - rata mahasiswa prodi D3 Keprawatan FMIPA menyimpulkan peminjaman alat-alat laboratorium menggunakan aplikasi google form lebih efisien. Dengan menyukai peminjaman alat secara online yang mudah di akses mahasiswa menganggap lebih efisien karena lebih praktis tinggal mengisi peminjaman online mahasiswa sudah dapat melakukan peminjaman alat tanpa harus melakukan copy ataupun mengeprintkannya

4. Menggunakan Google Form dapat menghemat kertas

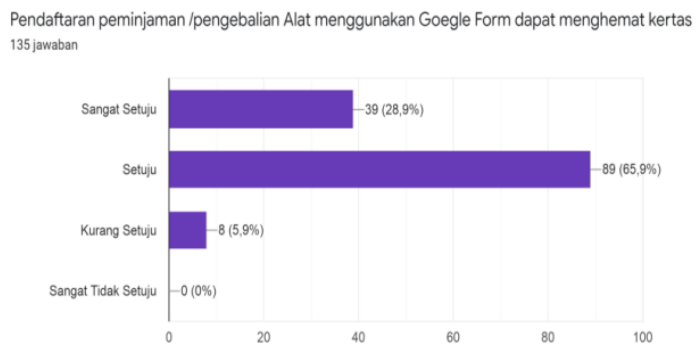

Berdasarkan data pada gambar 2 diperoleh hasil, respon responden yang memberikan respon terhadap Kuesioner evaluasi pemanfaatan google form sebagai alat peminjaman dan pengembalian dalam pengelolan Laboratorium Keperawatan Masa Pandemi Covid 19 adalah yang menyatakan sangat setuju 39 orang $(28,9 \%)$ setuju berjumlah 89 Orang $(65,9 \%)$, kurang setuju 8 orang $(5,9 \%)$ dan sangat tidak setuju berjumlah 0 orang $(0 \%)$.

Dari data diatas dapat disimpulkan bahwa rata - rata mahasiswa prodi D3 Keprawatan FMIPA menyimpulkan peminjaman alat-alat laboratorium menggunakan aplikasi google form lebih efisien. Dengan menyukai peminjaman alat secara online yang mudah di akses mahasiswa 
menganggap lebih efisien karena lebih praktis dan menghemat kertas, karena rekapan peminjaman alat dapat disimpan dalam rekapan google form itu sendiri.

5. Menggunakan Google Form mudah di pahami

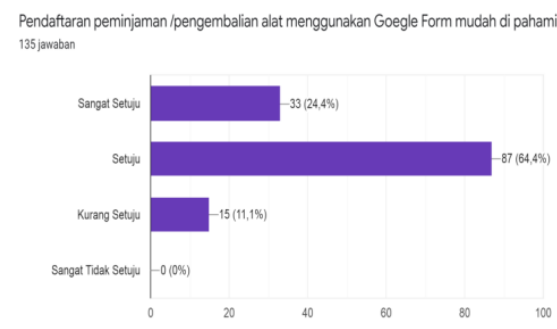

Berdasarkan data pada gambar 2 diperoleh hasil, respon responden yang memberikan respon terhadap Kuesioner evaluasi pemanfaatan google form sebagai alat peminjaman dan pengembalian dalam pengelolan Laboratorium Keperawatan Masa Pandemi Covid 19 adalah yang menyatakan sangat setuju 33 orang $(24,4 \%)$ setuju berjumlah 87 Orang $(64,4 \%)$, kurang setuju 15 orang $(11,1 \%)$ dan sangat tidak setuju berjumlah 0 orang $(0 \%)$.

Dari data diatas dapat disimpulkan bahwa rata - rata mahasiswa prodi D3 Keprawatan FMIPA menyimpulkan peminjaman alat-alat laboratorium menggunakan aplikasi google form lebih efisien. Dengan menyukai peminjaman alat secara online yang mudah dipahami karena menggunakan aplikasi google form mudah di akses dimanapun dan kapanpun tanpa harus memahami yang sulit.

6. menggunakan Google Form menarik dan mudah di mengerti

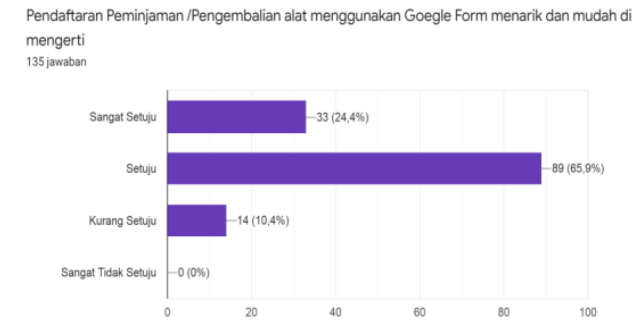

Berdasarkan data pada gambar 2 diperoleh hasil, respon responden yang memberikan respon terhadap Kuesioner evaluasi pemanfaatan google form sebagai alat peminjaman dan pengembalian dalam pengelolan Laboratorium Keperawatan Masa Pandemi Covid 19 adalah yang menyatakan sangat setuju 33 orang $(24,4 \%)$ setuju berjumlah 89 Orang $(65,9 \%)$, kurang setuju 14 orang $(10,4 \%)$ dan sangat tidak setuju berjumlah 0 orang $(0 \%)$.

Dari data diatas dapat disimpulkan bahwa rata - rata mahasiswa prodi D3 Keprawatan FMIPA menyimpulkan peminjaman alat-alat laboratorium menggunakan aplikasi google form menarik dan mudah di mengerti. Penyajian kuis yang di sertai dengan gambar dan fitur berupa pemandangan, gambar kekhasan dari kuis, membuat kuesioner jadi lebih indah dan menarik. Serta petunjuk kuis yang ada didalam google form tidak sulit sehingga dalam menggunakannya sangat mudah bagi mahasiswa dalam merespon penggunaan aplikasi ini.

7. Bahasa yang digunakan dalam Google Form sudah sesuai 


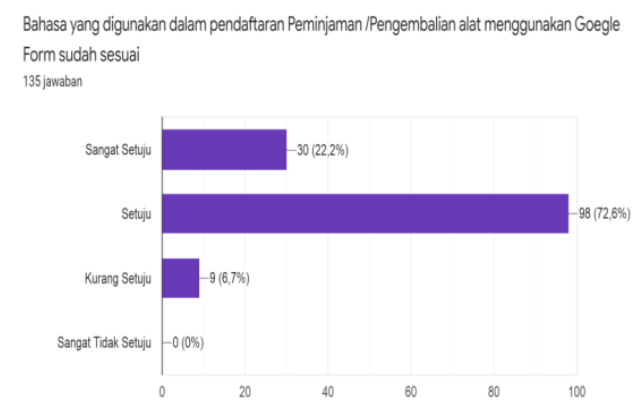

Berdasarkan data pada gambar 2 diperoleh hasil, respon responden yang memberikan respon terhadap Kuesioner evaluasi pemanfaatan google form sebagai alat peminjaman dan pengembalian dalam pengelolan Laboratorium Keperawatan Masa Pandemi Covid 19 adalah yang menyatakan sangat setuju 30 orang (22\%) setuju berjumlah 98 Orang (72,6\%), kurang setuju 9 orang $(6,7 \%)$ dan sangat tidak setuju berjumlah 0 orang $(0 \%)$.

Dari data diatas dapat disimpulkan bahwa rata - rata mahasiswa prodi D3 Keprawatan FMIPA menyimpulkan peminjaman alat-alat laboratorium menggunakan aplikasi google form sudah sesuai untuk kondisi saat ini. Sehingga mahasiswa cukup mengisi link peminjaman dan pengembalian alat ini tan harus bertemu dengan PLP laboratorium keperawatan.

\section{KESIMPULAN}

Berdasarkan hasil penelitian terhadap pemanfaatan teknologi informasi dan komunikasi pada pada peminjaman alat dan bahan laboratorium keperawatan, dapat ditarik simpulan berikut : Menyukai pelayanan laboratorium menggunakan Google Form di masa pandemi Covid-19. (1) Menggunakan Google Form mudah di akses memperoleh hasil $81 \%$, (2) Menggunakan Google Form mudah di akses memperoleh hasil 70 \% (3) Menggunakan Google Form dapat menghemat kertas memperoleh hasil $66 \%$ (4) Menggunakan Google Form mudah di pahami memperoleh hasil $88 \%$, (5) Menggunakan Google Form menarik dan mudah di mengerti Memperoleh hasil $90 \%$, (6) Bahasa yang digunakan dalam Google Form sudah sesuai memperoleh hasil $73 \%$.

\section{DAFTAR PUSTAKA}

Batubara, Hamdan Husein. "Penggunaan google form sebagai alat penilaian kinerja dosen di Prodi PGMI Uniska Muhammad Arsyad Al Banjari." Al-Bidayah: Jurnal Pendidikan Dasar Islam 8.1 (2016).

Indonesia, Republik. "Peraturan Menteri Kesehatan Republik Indonesia Nomor 9 Tahun 2020 Tentang Pedoman Pembatasan Sosial Berskala Besar Dalam Rangka Percepatan Penanganan Corona Virus Disease 2019 (Covid-19)." Jakarta: Kemeterian Kesehatan Republik Indonesia (2020). 